\title{
Optimizing safety of COPD treatments: role of the nurse practitioner
}

\author{
This article was published in the following Dove Press journal: \\ Journal of Multidisciplinary Healthcare \\ 20 February 2013 \\ Number of times this article has been viewed
}

\author{
Pamela Spencer' \\ Nicola A Hanania ${ }^{2}$ \\ 'Palliative Care and Surgery, Veteran's \\ Affairs Medical Center, Saginaw, \\ MI, USA; ${ }^{2}$ Section of Pulmonary \\ and Critical Care Medicine, Baylor \\ College of Medicine, Houston, TX, \\ USA
}

\begin{abstract}
As the prevalence of chronic obstructive pulmonary disease (COPD) continues to grow, management of the disease still faces considerable challenges. Despite the existence of effective pharmacological treatments, patient adherence is often poor. Side effects of medications and patients' concerns about potential side effects may contribute to poor adherence. Situated as they are at the frontline of patient care in the clinic, nurse practitioners play an important role in the management of COPD. This review discusses the current literature on medications available for management of COPD, focusing primarily on their safety and tolerability. This information can be particularly important for nurse practitioners, who can be invaluable in identifying side effects, and providing education to patients with COPD on the available treatments and the associated side effects. By helping patients to understand the balance of benefits and risks of treatment, nurse practitioners may be able to help improve adherence and thereby improve patient outcomes.
\end{abstract}

Keywords: chronic obstructive pulmonary disease, safety, treatment, role, nurse practitioner

\section{Introduction}

Chronic obstructive pulmonary disease (COPD) is the third leading cause of death and the fastest growing of the major causes of mortality in the United States. ${ }^{1}$ More than 12 million adults were diagnosed with COPD in 2007, ${ }^{2}$ and it has been estimated that a similar number of people with the disease remain undiagnosed. ${ }^{3}$ Nurse practitioners are ideally placed to play an important role in the early diagnosis and management of COPD. As the prevalence of COPD rises, these patients are likely to make up an increasing proportion of the nurse practitioner's caseload.

Management of COPD involves both pharmacological and nonpharmacological aspects. Pharmacological management can be complex because COPD is a chronic, progressive condition in patients who often suffer from comorbidities. ${ }^{4}$ As with many chronic conditions, patients with COPD may require long-term treatment, which may increase the risk of adverse events and raise concerns about adherence to prescribed medication. Chronic disease management increasingly involves a collaborative team approach, with nurse practitioners central to the team, although distribution of tasks between team members varies. The purpose of this review is to discuss the role of nurse practitioners in the management of patients with COPD, with a particular focus on issues concerning the safety and tolerability of pharmacological therapy.
Correspondence: Pamela Spencer 7898 North Michigan, Saginaw, MI 48604, USA

Tel +l 9897538613

Fax + I $98939 \mid 4916$

Email pamela.spencer@va.gov 


\section{COPD: an overview}

The chronic airway limitation characteristic of COPD is due to inflammation that results in obstruction of the small airways and destruction of lung parenchyma. ${ }^{4}$ Common symptoms include chronic cough, sputum production, and progressive, persistent dyspnea that worsens with exertion. COPD can be prevented and existing COPD can be treated, but the disease is incurable and the airway limitation is not fully reversible. ${ }^{4}$ As COPD progresses, patients are forced to limit their activities and may experience depression and a decline in their quality of life. ${ }^{5}$ Patients with COPD also commonly experience comorbid conditions related to aging and/or smoking, including cardiovascular disease, osteoporosis, and depression. ${ }^{4}$

Smoking is by far the most common risk factor for development of COPD, but other factors such as outdoor, occupational, and indoor air pollution may also cause COPD in the absence of smoking. ${ }^{4}$ Factors such as genetics, infections, nutrition, and oxidative stress may also have a role in the development and/or progression of COPD. The prevalence of COPD rises sharply with age; ${ }^{6}$ a meta-analysis of studies from 28 countries estimated the prevalence of COPD in individuals aged $\geq 40$ years at $9.7 \%$ and in individuals aged $\geq 65$ years at $15.0 \%$. $^{7}$ Furthermore, even if smoking rates were to decline dramatically, the prevalence of COPD may continue to rise over the coming years due to aging of the population and the history of smoking. ${ }^{8}$ Historically, the prevalence of COPD has been higher among men than women, although recent trends suggest that this gender difference may be declining in regions where smoking rates are similar between the genders. ${ }^{9}$ Despite the existence of risk factors and development of symptoms, many patients may be unaware of existing COPD. For example, a meta-analysis on the global prevalence of the disease estimated that $9.2 \%$ of the population met spirometric criteria for COPD but only $4.9 \%$ reported a doctor's diagnosis of the disease. ${ }^{7}$

National and international guidelines, including those prepared by the Global Initiative for Chronic Obstructive Lung Disease (GOLD), ${ }^{4}$ American Thoracic Society/ European Respiratory Society, ${ }^{10}$ and Canadian Thoracic Society, ${ }^{11}$ provide recommendations for the diagnosis, management, and treatment of COPD. According to the GOLD guidelines updated in December 2011, spirometry is now required to make a confident diagnosis of COPD, whereas previously it was used to support the diagnosis. ${ }^{4}$ The fixed ratio of postbronchodilator forced expiratory volume in one second $\left(\mathrm{FEV}_{1}\right)$ to the forced vital capacity $(\mathrm{FVC})$, or $\mathrm{FEV}_{1} / \mathrm{FVC}$, needs to be $<70 \%{ }^{4}$ and the staging system of spirometric classification, which has now been replaced with grading, uses: $\mathrm{FEV}_{1} \geq 80 \%$ predicted (GOLD 1, mild); $50 \% \leq \mathrm{FEV}_{1}<80 \%$ predicted (GOLD 2, moderate); $30 \% \leq \mathrm{FEV}_{1}<50 \%$ predicted (GOLD 3, severe); and $\mathrm{FEV}_{1}<30 \%$ predicted (GOLD 4 , very severe). In order to assess symptoms in patients, the GOLD guidelines suggest the use of the Modified British Medical Research Council questionnaire or the COPD Assessment Test. ${ }^{4}$ Canadian Thoracic Society guidelines also suggest incorporating measures of dyspnea and disability into clinical assessment of disease severity to individualize management decisions. ${ }^{11}$ It is not always possible to distinguish COPD from chronic asthma in some patients, so it is assumed that the two exist together. ${ }^{4}$

One of the most important initial steps for management of COPD is to reduce exposure to risk factors, including cigarette smoke and/or occupational dusts, fumes, and gases. Given the leading role of smoking as a cause of COPD, it may not be surprising that smoking cessation is the only intervention shown to reduce the rate of disease progression and related mortality. ${ }^{12}$ Patient education is a particularly important component of smoking cessation intervention, and education about some aspects of COPD may help patients to cope. ${ }^{4}$

Pharmacological therapies are useful to manage symptoms, and some are indicated to reduce exacerbations, which become increasingly important goals as the disease progresses. Various classes of drugs may be appropriate based on the patient's symptoms, risk of exacerbation, and grade of airflow limitation (Table 1). ${ }^{4}$ In general, short-acting bronchodilators are recommended as needed at all stages of the disease, and long-acting bronchodilators may be appropriate as regular maintenance therapy for patients with moderate to severe COPD. The long-acting anticholinergic, tiotropium, was also recently approved for reduction of exacerbations in patients with COPD.

An inhaled corticosteroid (ICS) may be appropriate as add-on therapy to long-acting bronchodilators in patients with severe and very severe COPD. For instance, a combination of the long-acting $\beta$-adrenergic, salmeterol, and fluticasone, an ICS, is indicated to reduce exacerbations in patients with COPD with a history of exacerbations. ${ }^{4}$ Systemic corticosteroids are recommended in the treatment of acute exacerbations of COPD, but their long-term use is not recommended due to lack of evidence of benefit and side effects. ${ }^{13}$

The 3-year TOwards a Revolution in COPD Health (TORCH) ${ }^{14}$ and 4-year Understanding Potential Long-term Impacts on Function with Tiotropium (UPLIFT) ${ }^{15}$ trials 
Table I Therapy at each grade of chronic obstructive pulmonary disease as recommended by GOLD (Global Initiative for Chronic Obstructive Lung Disease)

\begin{tabular}{|c|c|c|c|}
\hline Patient group & First choice & Second choice & Alternative choice $^{b}$ \\
\hline \multicolumn{4}{|c|}{ Initial pharmacologic management of COPD ${ }^{a}$} \\
\hline A & $\begin{array}{l}\text { Short-acting anticholinergic prn } \\
\text { or } \\
\text { short-acting beta }{ }_{2} \text {-agonist prn }\end{array}$ & $\begin{array}{l}\text { Long-acting anticholinergic } \\
\text { or } \\
\text { long-acting beta }{ }_{2} \text {-agonist } \\
\text { or } \\
\text { short-acting beta } 2 \text {-agonist and short-acting anticholinergic }\end{array}$ & Theophylline \\
\hline B & $\begin{array}{l}\text { Long-acting anticholinergic } \\
\text { or } \\
\text { long-acting beta }{ }_{2} \text {-agonist }\end{array}$ & Long-acting anticholinergic and long-acting beta ${ }_{2}$-agonist & $\begin{array}{l}\text { Short-acting beta }{ }_{2} \text {-agonist } \\
\text { and/or } \\
\text { short-acting anticholinergic } \\
\text { Theophylline }\end{array}$ \\
\hline C & $\begin{array}{l}\text { Inhaled corticosteroid + long- } \\
\text { acting beta }{ }_{2} \text {-agonist } \\
\text { or } \\
\text { long-acting anticholinergic }\end{array}$ & Long-acting anticholinergic and long-acting beta ${ }_{2}$-agonist & $\begin{array}{l}\text { Phosphodiesterase-4 inhibitor } \\
\text { Short-acting beta }{ }_{2} \text {-agonist } \\
\text { and/or } \\
\text { short-acting anticholinergic } \\
\text { Theophylline }\end{array}$ \\
\hline D & $\begin{array}{l}\text { Inhaled corticosteroid + long- } \\
\text { acting beta }{ }_{2} \text {-agonist } \\
\text { or } \\
\text { long-acting anticholinergic }\end{array}$ & $\begin{array}{l}\text { Inhaled corticosteroid and long-acting anticholinergic } \\
\text { or } \\
\text { inhaled corticosteroid + long-acting beta }{ }_{2} \text {-agonist and } \\
\text { long-acting anticholinergic } \\
\text { or } \\
\text { inhaled corticosteroid + long-acting beta } 2 \text {-agonist } \\
\text { and phosphodiesterase-4 inhibitor } \\
\text { or } \\
\text { long-acting anticholinergic } \\
\text { and long-acting beta } 2 \text {-agonist } \\
\text { or } \\
\text { long-acting anticholinergic and phosphodiesterase- } 4 \text { inhibitor }\end{array}$ & $\begin{array}{l}\text { Carbocysteine } \\
\text { Short-acting beta } 2 \text {-agonist } \\
\text { and/or } \\
\text { short-acting anticholinergic } \\
\text { Theophylline }\end{array}$ \\
\hline
\end{tabular}

Notes: Group A: few symptoms and low risk of exacerbations. GOLD I or 2 (mild/moderate airflow limitation) and/or 0-I exacerbation per year and mMRC grade 0-I or CAT score < 10. Group B: more significant symptoms; low risk of exacerbations. GOLD I or 2 (mild/moderate airflow limitation) and/or 0-I exacerbation per year and mMRC grade $\geq 2$ or CAT score $\geq 10$. Group C: few symptoms; high risk of exacerbations. GOLD 3 or 4 (severe/very severe airflow limitation) and/or $\geq 2$ exacerbations per year and mMRC grade $0-1$ or CAT score < 10. Group D: many symptoms; high risk of exacerbations. GOLD 3 or 4 (severe/very severe airflow limitation) and/or $\geq 2$

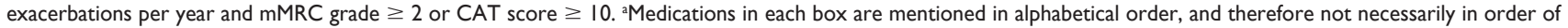
preference; bmedications in this column can be used alone or in combination with other options in the first and second columns.

${ }^{a}$ Copyright @ 20 I , Global Initiative for Chronic Obstructive Lung Disease. Reproduced with permission from Global Initiative for Chronic Obstructive Lung Disease. Global strategy for the diagnosis, management, and prevention of chronic obstructive pulmonary disease. Updated Dec 20II. Available from: http://www.goldcopd.org. Accessed July 5, 20I2. ${ }^{4}$

Abbreviations: CAT, COPD Assessment Test; COPD, chronic obstructive pulmonary disease; mMRC, Modified British Medical Research Council; prn, taken as needed.

both included mortality as an endpoint. In TORCH, the difference in mortality between the salmeterol/fluticasone and placebo treatment groups did not reach statistical significance (salmeterol/fluticasone $12.6 \%$, placebo $15.2 \%$; hazard ratio [HR] 0.825; 95\% confidence interval [CI]: 0.681-1.002; $P=0.052) .{ }^{14}$ In UPLIFT, all-cause mortality was significantly lower in the tiotropium group compared with placebo while patients were receiving treatment (up to day 1440 , tiotropium $14.4 \%$, placebo $16.3 \%$; HR 0.87 ; 95\% CI: 0.76-0.99) but not significantly different when data from the following 30 days were included (up to day 1470, tiotropium $14.9 \%$, placebo 16.5\%; HR 0.89; 95\% CI: 0.79-1.02). ${ }^{15,16}$ In both TORCH and

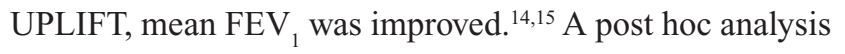
of TORCH suggested that salmeterol/fluticasone reduced the rate of $\mathrm{FEV}_{1}$ decline compared with placebo. ${ }^{17}$ These treatments and the associated side effects are considered in more detail in the following section.

\section{Safety and tolerability of COPD medications}

Table 2 summarizes the side effects of COPD treatments observed in clinical practice, and outlines alerts for nurse practitioners, derived from cautions described in the product prescribing information. Most side effects experienced with medications for COPD are relatively minor, and are bothersome to the patient rather than actually harmful; however, rare side effects that are potentially very serious may occur, and associations with other side effects have been reported, although a definite link to treatment is not proven in all cases (Table 2). Both the experience of unpleasant side effects and a lack of patient knowledge about the disease and treatments can increase the risk of nonadherence. ${ }^{18}$ The discussion below addresses side effects frequently encountered in clinical practice, either as actual events experienced by patients or as potential concerns expressed by the patient. 
Table 2 Most common potential side effects reported with COPD medications

\begin{tabular}{|c|c|c|}
\hline Drug class & Side effects ${ }^{a}$ & Nurse practitioner alert ${ }^{b}$ \\
\hline $\begin{array}{l}\text { Inhaled } \beta_{2} \text {-agonists } \\
\text { SABAs (albuterol and levalbuterol) } \\
\text { and LABAs (salmeterol and formoterol) }\end{array}$ & $\begin{array}{l}\text { Headache }^{14,19-22} \\
\text { Pharyngitis }^{20,23} \\
\text { Musculoskeletal pain }^{19,20,24,25} \\
\text { Elevated heart rate } \\
\text { Elevated blood pressure } \\
\text { Hyperglycemia } \\
\text { Hypokalemia } \\
\text { Palpitation } \\
\text { Tremor } \\
\text { Cardiovascular adverse effects } \\
\text { Increased mortalityc }\end{array}$ & $\begin{array}{l}\text { Cardiovascular disease, diabetes mellitus, glaucoma, } \\
\text { hyperthyroidism, hypokalemia, seizure disorders }\end{array}$ \\
\hline $\begin{array}{l}\text { Inhaled anticholinergics } \\
\text { SAACs (ipratropium) and LAACs (tiotropium) }\end{array}$ & $\begin{array}{l}\text { Dry mouth } \\
\text { Bitter taste }^{156-28} \\
\text { Constipation }^{15,27} \\
\text { Cough } \\
\text { Headache } \\
\text { Nausea } \\
\text { Pain } \\
\text { Increased ocular pressure } \\
\text { Urinary flow obstruction }\end{array}$ & $\begin{array}{l}\text { Glaucoma, prostatic hyperplasia, or bladder-neck } \\
\text { obstruction } \\
\text { Avoid spraying aerosol into eyes }\end{array}$ \\
\hline Methylxanthines (theophylline) & $\begin{array}{l}\text { Tremor }^{29} \\
\text { Nausea }^{29,30} \\
\text { Vomiting }^{29} \\
\text { Arrhythmias } \\
\text { Seizures } \\
\text { Abdominal pain } \\
\text { Diarrhea } \\
\text { Hypokalemia } \\
\text { Hyperglycemia } \\
\text { Sinus tachycardia } \\
\text { Nervousness }\end{array}$ & $\begin{array}{l}\text { Use with extreme caution in peptic ulcer disease, seizure } \\
\text { disorders, cardiac arrhythmias } \\
\text { Need for more intensive monitoring in patients }>60 \\
\text { years, acute pulmonary edema, congestive heart failure, } \\
\text { cor pulmonale, fever, hypothyroidism, liver disease, } \\
\text { sepsis with multiorgan failure, shock, smoking } \\
\text { Care with drug-drug interactions and toxicity }\end{array}$ \\
\hline $\begin{array}{l}\text { Corticosteroids } \\
\text { Inhaled (fluticasone, budesonide, mometasone, } \\
\text { beclomethasone, flunisolide, ciclesonide) }\end{array}$ & $\begin{array}{l}\text { Hoarseness }^{31,32} \\
\text { Oral candidiasis }{ }^{14,31-34} \\
\text { Skin bruising } \\
\text { Pneumonia } \\
\text { Osteoporosis } \\
\text { Cataracts } \\
\text { Glaucoma }\end{array}$ & $\begin{array}{l}\text { Patients transferring from oral steroids, emerging } \\
\text { allergies, reduced liver function, pulmonary tuberculosis }\end{array}$ \\
\hline Oral (prednisone, prednisolone) & $\begin{array}{l}\text { Hyperglycemia }{ }^{35-40} \\
\text { Insomnia }^{35,40} \\
\text { Weight gain }^{35,40} \\
\text { Hoarseness } \\
\text { Oral candidiasis } \\
\text { Skin bruising } \\
\text { Myopathy (long-term use) } \\
\text { Respiratory failure (long-term use) } \\
\text { Facial erythema } \\
\text { Fluid retention } \\
\text { Headache } \\
\text { Hypertension } \\
\text { Hypokalemic alkalosis } \\
\text { Impaired wound healing } \\
\text { Loss of muscle mass } \\
\text { Menstrual irregularities } \\
\text { Muscle weakness } \\
\text { Pathologic fracture } \\
\text { Potassium loss }\end{array}$ & $\begin{array}{l}\text { Needs gradual reduction of dosage after prolonged use } \\
\text { Enhanced effect on patients with hypothyroidism and } \\
\text { cirrhosis } \\
\text { Ocular herpes } \\
\text { Psychic derangements, emotional instability, psychotic } \\
\text { tendencies } \\
\text { Ulcerative colitis, diverticulitis, fresh intestinal } \\
\text { anastomoses, peptic ulcer, renal insufficiency, } \\
\text { hypertension, osteoporosis, myasthenia gravis } \\
\text { Kaposi's sarcoma } \\
\text { Discontinuation of corticosteroids may result in clinical } \\
\text { remission } \\
\text { Drug-drug interaction with cyclosporin }\end{array}$ \\
\hline
\end{tabular}


Table 2 (Continued)

\begin{tabular}{|c|c|c|}
\hline Drug class & Side effects ${ }^{a}$ & Nurse practitioner alert ${ }^{b}$ \\
\hline & Sodium retention & \\
\hline & Tendon rupture & \\
\hline & Thin fragile skin & \\
\hline & Abdominal distension & \\
\hline & Cataracts & \\
\hline & Convulsions & \\
\hline & Glaucoma & \\
\hline & Osteoporosis & \\
\hline & Pneumonia & \\
\hline & Vertigo & \\
\hline
\end{tabular}

Notes: aSide effects most commonly identified in randomized clinical trials shown in bold; berived from warnings in prescribing information; 'suggested side effects (cause not proven).

Abbreviations: SABAs, short-acting $\beta_{2}$-agonists; LABAs, long-acting $\beta_{2}$-agonists; SAAC, short-acting anticholinergic; LAAC, long-acting anticholinergic.

\section{Short-acting bronchodilators}

Short-acting bronchodilators include short-acting $\beta_{2}$-agonists and the short-acting anticholinergic agent, ipratropium. ${ }^{4}$

\section{Short-acting $\beta_{2}$-agonists}

Short-acting $\beta_{2}$-agonists, such as albuterol and levalbuterol, are usually available in a pressurized metered-dose inhaler or as a solution for nebulization, and are recommended for as-needed use to relieve symptoms at all stages of COPD. These agents are generally well tolerated, but patients may suffer from occasional troublesome class side effects, such as hypokalemia, hyperglycemia, elevated heart rate, tremors, headache, and palpitation, which are well established, predictable, and dose related (Table 2) ${ }^{41,42}$

Potential concerns about possible cardiovascular side effects and increased mortality associated with $\beta_{2}$-agonists (particularly fenoterol) used to treat asthma were raised in the late 1980s. Although further studies and meta-analyses have provided conflicting evidence, ${ }^{43,44}$ the GOLD guidelines indicate that no association has been found between $\beta_{2}$-agonist use and increased mortality in COPD (Table 3). However, adverse effects may occur more frequently in patients with underlying cardiac comorbidities; therefore, short-acting $\beta_{2}$-agonists should be used with care in patients with cardiovascular disease.

\section{Ipratropium bromide}

Ipratropium is well established as a short-acting bronchodilator in COPD, available in a pressurized metered-dose inhaler or as a solution for nebulization, and indicated for regular use four times daily as maintenance therapy for COPD. As with other anticholinergics, dry mouth is the main side effect of this drug. ${ }^{54}$ Other side effects include increased intraocular pressure and urinary outflow obstruction (Table 2), so care should be taken with ipratropium in patients with glaucoma or prostatic hyperplasia. ${ }^{54-56}$ Some patients complain of a bitter taste, though this may be considered a difference from other treatments rather than a side effect. ${ }^{55}$ Some studies have also suggested a possible association between ipratropium and an increase in cardiovascular events and mortality (Table 3). 12,48,49 Evidence from a meta-analysis by Singh et al that considered ipratropium and tiotropium together suggested a possible association between anticholinergic treatment and increased mortality and cardiovascular events (Table 3).$^{50}$ However, the United States Food and Drug Administration recently concluded that the available evidence demonstrates that tiotropium does not increase the risk of stroke, heart attack, or death. ${ }^{57}$

\section{Long-acting bronchodilators}

Long-acting bronchodilators are recommended as regular maintenance therapy for patients with moderate to severe COPD (Table 1). ${ }^{4}$ They include long-acting $\beta_{2}$-agonists (LABAs) and the long-acting anticholinergic agent, tiotropium.

\section{Long-acting $\beta_{2}$-agonists}

LABAs are available in the United States as dry powder inhalers (salmeterol and formoterol) or as a solution for nebulization (formoterol and arformoterol), taken twice daily for maintenance therapy. The most common adverse events highlighted in the prescribing information for LABAs are similar to those for short-acting $\beta_{2}$-agonists (Table 2) ${ }^{58-60}$ Concerns about rare cardiovascular adverse effects and increased mortality have also been raised for LABAs, especially by studies in patients with asthma, but there is conflicting evidence on these side effects in patients with COPD (Table 3). The Salmeterol Multicenter Asthma Research Trial found a small 
Table 3 Conflicting evidence for increased risk of cardiovascular events and mortality with bronchodilators

\begin{tabular}{|c|c|c|c|}
\hline Drug class & Study description & Outcome & Reference \\
\hline \multirow[t]{2}{*}{ SABAs } & $\begin{array}{l}\text { Meta-analysis of randomized, placebo-controlled } \\
\text { trials of } \beta_{2} \text {-agonists in patients with obstructive } \\
\text { airways disease }(n=7962)\end{array}$ & $\begin{array}{l}\text { Increased risk versus placebo of adverse } \\
\text { cardiovascular events }\end{array}$ & Salpeter et al $\left.\right|^{43}$ \\
\hline & $\begin{array}{l}\text { Population-based cohort study of patients } \\
\text { with COPD }(n=12,090)\end{array}$ & $\begin{array}{l}\text { No increased risk of fatal or nonfatal acute } \\
\text { myocardial infarction }\end{array}$ & Suissa et $\mathrm{a}^{44}$ \\
\hline \multirow[t]{5}{*}{ LABAs } & $\begin{array}{l}\text { Meta-analysis of randomized, placebo-controlled } \\
\text { trials of } \beta_{2} \text {-agonists in patients with obstructive } \\
\text { airways disease }(n=7962)\end{array}$ & $\begin{array}{l}\text { Increased risk versus placebo of adverse } \\
\text { cardiovascular events }\end{array}$ & Salpeter et al ${ }^{43}$ \\
\hline & $\begin{array}{l}\text { Randomized, double-blind, placebo-controlled study } \\
\text { of formoterol in patients with COPD }(n=204)\end{array}$ & $\begin{array}{l}\text { No increased risk versus placebo of adverse } \\
\text { cardiovascular events }\end{array}$ & Campbell et $\mathrm{a}^{45}$ \\
\hline & $\begin{array}{l}\text { TORCH: randomized, double-blind, placebo- and } \\
\text { active-controlled trial of salmeterol and fluticasone } \\
\text { in patients with COPD }(n=6 \mid I 2)\end{array}$ & $\begin{array}{l}\text { No increased risk of mortality for salmeterol } \\
\text { or salmeterol-fluticasone combination versus } \\
\text { placebo }\end{array}$ & Calverley et al ${ }^{14}$ \\
\hline & $\begin{array}{l}\text { Meta-analysis of randomized, controlled trials } \\
\text { of salmeterol and formoterol versus placebo or } \\
\text { anticholinergics in patients with COPD }(n=20,527)\end{array}$ & $\begin{array}{l}\text { No increased risk of respiratory death } \\
\text { versus placebo }\end{array}$ & Rodrigo et $\mathrm{al}^{46}$ \\
\hline & $\begin{array}{l}\text { Meta-analysis of randomized, double-blind, } \\
\text { placebo-controlled trials of salmeterol } \\
\text { in patients with COPD }(n=1443)\end{array}$ & $\begin{array}{l}\text { No increased risk of cardiovascular events } \\
\text { versus placebo }\end{array}$ & Ferguson et $\mathrm{al}^{47}$ \\
\hline \multirow[t]{9}{*}{ Anticholinergics } & $\begin{array}{l}\text { Lung Health Study: randomized, placebo-controlled } \\
\text { trial of smoking intervention and ipratropium } \\
\text { in patients with mild to moderate lung function } \\
\text { impairment }(n=5887)\end{array}$ & $\begin{array}{l}\text { Increased risk of death and hospitalization for } \\
\text { cardiovascular disease and coronary artery disease } \\
\text { versus placebo (approached statistical significance) }\end{array}$ & Anthonisen et $\mathrm{al}^{12}$ \\
\hline & $\begin{array}{l}\text { Cohort study of ipratropium in patients } \\
\text { with COPD }(n=82,717)\end{array}$ & Increased risk of cardiovascular events & Ogale et $\mathrm{al}^{48}$ \\
\hline & $\begin{array}{l}\text { Case-control study of various respiratory } \\
\text { medications in patients with COPD } \\
(n=32,130 \text { cases and } 320,501 \text { controls) }\end{array}$ & $\begin{array}{l}\text { Increased risk of all-cause and cardiovascular } \\
\text { mortality with ipratropium }\end{array}$ & Lee et $\mathrm{al}^{49}$ \\
\hline & $\begin{array}{l}\text { Meta-analysis of randomized, controlled trials of } \\
\text { anticholinergics in patients with COPD }(n=14,783)\end{array}$ & $\begin{array}{l}\text { Increased risk of cardiovascular mortality, myocardial } \\
\text { infarction, or stroke (composite endpoint) }\end{array}$ & Singh et $\mathrm{al}^{50}$ \\
\hline & $\begin{array}{l}\text { Meta-analysis of randomized, double-blind, } \\
\text { placebo-controlled trials of tiotropium in patients } \\
\text { with obstructive lung disease }(n=7819)\end{array}$ & $\begin{array}{l}\text { No increased risk of all-cause, respiratory, } \\
\text { and cardiovascular mortality }\end{array}$ & Kesten et $\mathrm{al}^{27}$ \\
\hline & $\begin{array}{l}\text { Meta-analysis of randomized, placebo-controlled } \\
\text { or active-controlled trials of tiotropium in patients } \\
\text { with COPD }(n=8002)\end{array}$ & $\begin{array}{l}\text { No increased risk of pulmonary or all-cause } \\
\text { mortality versus placebo }\end{array}$ & Barr et $\mathrm{al}^{51}$ \\
\hline & $\begin{array}{l}\text { UPLIFT: randomized, double-blind, } \\
\text { placebo-controlled trial of tiotropium }(n=5993)\end{array}$ & No increased risk of mortality versus placebo & Tashkin et al ${ }^{15}$ \\
\hline & $\begin{array}{l}\text { Meta-analysis following methodology } \\
\text { of Singh et al, },^{50} \text { adding UPLIFT data }\end{array}$ & $\begin{array}{l}\text { No increased risk of cardiovascular mortality, } \\
\text { myocardial infarction, or stroke (composite endpoint) }\end{array}$ & Oba et $\mathrm{a}^{52}$ \\
\hline & $\begin{array}{l}\text { Pooled analysis of } 30 \text { double-blind, } \\
\text { placebo-controlled studies }(n=19,545)\end{array}$ & $\begin{array}{l}\text { Decreased risk of all-cause mortality and } \\
\text { cardiovascular events (composite endpoint) }\end{array}$ & Celli et a $\left.\right|^{53}$ \\
\hline
\end{tabular}

Notes: Shaded areas indicate studies showing increased risk; unshaded areas indicate studies showing no increased risk.

Abbreviations: SABAs, short-acting $\beta_{2}$-agonists; LABAs, long-acting $\beta_{2}$-agonists; TORCH, TOwards a Revolution in COPD Health; UPLIFT, Understanding Potential Longterm Impacts on Function with Tiotropium study.

but significant increased risk of respiratory/asthma-related mortality compared with placebo in patients with asthma ${ }^{61}$ and a meta-analysis of studies of LABAs in patients with COPD and asthma found an increased risk of treatmentrelated cardiovascular events. ${ }^{43}$ In contrast, no increased risk compared with placebo was found in two other studies, ${ }^{14,45}$ a systematic review, ${ }^{46}$ and a pooled analysis ${ }^{47}$ that included only patients with COPD. The Food and Drug Administration has now recommended that LABAs should not be used without an asthma controller medication for treatment of patients with asthma, ${ }^{62}$ but LABAs are still approved as monotherapy for management of COPD.

\section{Tiotropium bromide}

Tiotropium bromide is the only long-acting anticholinergic on the market, and is available in a dry powder inhaler. It is taken once daily as a maintenance bronchodilator therapy and is indicated for reduction of exacerbations in COPD. ${ }^{63}$ 
Adverse effects associated with tiotropium are similar to those observed with ipratropium, with the most common side effect being dry mouth (Table 2). ${ }^{52,63}$ Again, tiotropium should be used with caution in patients with glaucoma or prostatic hyperplasia.

Although the meta-analysis by Singh et al that considered ipratropium and tiotropium together suggested a possible association between anticholinergic treatment and increased mortality and cardiovascular events (Table 3 ), ${ }^{50}$ another metaanalysis $^{51}$ and two pooled analyses ${ }^{27,53}$ showed no increased risk with tiotropium treatment. Furthermore, results from the UPLIFT study, a large-scale, 4-year, randomized controlled trial, indicated that tiotropium reduced cardiac morbidity. ${ }^{15}$ In light of these data, the Food and Drug Administration recently concluded that tiotropium does not increase the risk of stroke, heart attack, or death. ${ }^{57}$

\section{Methylxanthines}

Theophylline is the most widely used methylxanthine in the treatment of COPD, but owing to toxicity at higher doses, other bronchodilators are usually preferred. ${ }^{4}$ Dose-related adverse effects include nausea, vomiting, seizures, and arrhythmias (Table 2). ${ }^{64}$

\section{Corticosteroids}

\section{Inhaled corticosteroids}

ICS are recommended as add-on therapy in combination with long-acting bronchodilators for patients with severe and very severe COPD (Table 1). ${ }^{4}$ The most commonly prescribed ICS are fluticasone ${ }^{65}$ and budesonide. ${ }^{66}$ They are available as pressurized metered-dose inhalers or dry powder inhalers, and are usually administered twice daily. ICS are not recommended for monotherapy in COPD.
Common side effects of ICS include bruising of the skin, ${ }^{31,32}$ oral candidiasis, and hoarseness (Table 2) ${ }^{67}$ More serious side effects that may occur in a small number of patients include pneumonia and a reduction in bone mineral density (a precursor to osteoporosis). An increased risk of pneumonia with ICS in patients with COPD has been shown in several randomized trials $\mathrm{s}^{14,68-70}$ and a meta-analysis. ${ }^{71}$ There is evidence both supporting ${ }^{72-74}$ and refuting ${ }^{75,76}$ the effect of ICS on bone mineral density and/or bone fractures (Table 4). The results from these studies may be confounded by disease severity, ${ }^{77}$ but it is still recommended that bone mineral density is assessed prior to prescribing any ICS in COPD and that it is carried out periodically thereafter. There is also a small risk of a dose-dependent increase in cataracts and glaucoma with $\mathrm{ICS}^{67}$ and it is recommended that regular eye examinations be performed on patients receiving these drugs.

\section{Oral corticosteroids}

Oral corticosteroids, prednisone and prednisolone, may be administered in patients with very severe COPD and acute exacerbations, but long-term use is not recommended, especially at the high doses generally required, due to potentially harmful adverse events that may contribute to the development of diabetes, hypertension, osteoporosis, and steroidinduced myopathy (Table 2).,13

\section{Phosphodiesterase-4-inhibitors}

The phosphodiesterase-4-inhibitor, roflumilast, was approved by the Food and Drug Administration in 2011 to reduce the frequency of exacerbations in patients with severe COPD. Adverse events associated with roflumilast include diarrhea, weight loss, nausea, insomnia, headache, and back pain. ${ }^{78}$ In two clinical trials comparing the effect of salmeterol or

Table 4 Conflicting evidence for increased risk of bone mineral density loss with inhaled corticosteroids

\begin{tabular}{|c|c|c|}
\hline Study description & Outcome & Reference \\
\hline Lung Health Study: randomized, placebo-controlled study & Significantly lower bone density of the femur and lumbar & Lung Health Study \\
\hline of triamcinolone in patients with COPD $(n=1116)$ & spine versus placebo, but no increased risk of bone fracture & Research Group ${ }^{72}$ \\
\hline $\begin{array}{l}\text { Case-control analysis of patients with hip fracture in } \\
\text { general practice ( } n=16,341 \text { cases and } 29,899 \text { controls) }\end{array}$ & Higher risk of hip fracture with inhaled corticosteroids & Hubbard et $\mathrm{al}^{73}$ \\
\hline $\begin{array}{l}\text { Case-control study in COPD patients of the association } \\
\text { between inhaled corticosteroid use and vertebral } \\
\text { fractures ( } n=1708 \text { cases and } 6817 \text { controls) }\end{array}$ & $\begin{array}{l}\text { High doses of inhaled corticosteroid were associated } \\
\text { with an increased risk of vertebral fracture }\end{array}$ & Lee and Weiss ${ }^{74}$ \\
\hline $\begin{array}{l}\text { Randomized, placebo-controlled trial of budesonide } \\
\text { in patients with COPD }(n=912)\end{array}$ & $\begin{array}{l}\text { No change in bone mineral density or fracture } \\
\text { rates versus placebo }\end{array}$ & Johnell et $\mathrm{al}^{75}$ \\
\hline $\begin{array}{l}\text { TORCH: randomized, double-blind, placebo- and } \\
\text { active-controlled trial of salmeterol and fluticasone } \\
\text { in patients with COPD }(n=658)\end{array}$ & $\begin{array}{l}\text { No increased risk of bone mineral density loss or fractures } \\
\text { with fluticasone or salmeterol-fluticasone combination } \\
\text { versus placebo }\end{array}$ & Ferguson et $\mathrm{a}^{76}$ \\
\hline
\end{tabular}

Notes: Shaded areas indicate studies showing increased risk; unshaded areas indicate studies showing no increased risk. Abbreviations: COPD, chronic obstructive pulmonary disease; TORCH, TOwards a Revolution in COPD Health. 
tiotropium in the presence or absence of roflumilast, it was evident that weight loss was greater in patients also experiencing headache and/or gastrointestinal adverse events, indicating a causal relationship between these adverse events. ${ }^{79}$ As a consequence of the greater potential for weight loss with roflumilast, regular monitoring of weight should be encouraged in patients treated with this drug.

\section{Combination products}

Combination products, including ipratropium plus albuterol, ${ }^{80}$ salmeterol plus fluticasone, ${ }^{81}$ and formoterol plus budesonide, ${ }^{82}$ are commonly prescribed as maintenance therapy for patients with COPD. Salmeterol plus fluticasone is indicated to reduce the risk of exacerbations in patients with a history of exacerbations. ${ }^{81}$ Generally, the side effect profiles of the combination products reflect those of the individual components (Table 2), ${ }^{80-82}$ and no additional safety concerns have been reported.

\section{Role of the nurse practitioner in COPD}

COPD is a chronic disease, often with gradual onset, and is often seen in older patients who may have comorbidities that also require treatment, complicating its diagnosis and management. Limited physician time may lead to inadequacies in the diagnosis and management of COPD. ${ }^{83}$ Awareness of COPD and comorbid conditions among patients is low, ${ }^{84}$ and communication between patients and health care providers may be poor. ${ }^{85}$ Strengthening the role of the nurse practitioner in management of COPD could be an important strategy to improve patient education and communication. The scope of the nurse practitioner's role within the disease management team in COPD may vary between clinics, but could include diagnosis, prescription, patient monitoring, ongoing evaluation of treatment success, and modification of treatment where required (Figure 1). In some clinics, some of these roles may be carried out by other staff, while other tasks, such as writing and modifying prescriptions, are restricted to physicians and nurse practitioners.

As with other chronic diseases, adherence to therapy is often poor among patients with COPD. ${ }^{18,86}$ Patients may fail to adhere to treatment because they have inadequate knowledge of the disease and its treatments, ${ }^{18,86,87}$ which could potentially result in unrealistic expectations of treatment outcomes. Alternatively, patients may be discouraged by unpleasant side effects ${ }^{18}$ or reports of potential side effects. Even if the patient attempts to adhere to therapy, they may underuse, overuse, or improperly use the inhaler devices. ${ }^{18}$ Furthermore, patients

\begin{tabular}{ccc}
\multicolumn{1}{c}{ Reassurance } & $\begin{array}{c}\text { Context } \\
\text { Education }\end{array}$ & $\begin{array}{c}\text { Treatment risks } \\
\text { and benefits }\end{array}$ \\
Evaluation & Adherence \\
\cline { 2 - 3 } Monitoring & $\begin{array}{c}\text { Nurse } \\
\text { practitioner }\end{array}$ & Lifestyle \\
Prescription & & Expectations \\
review & & Inhaler \\
& Diagnosis &
\end{tabular}

Figure I Nurse practitioner's role in management of COPD.

may be prescribed several COPD medications as well as medications for other comorbidities, thus complicating the treatment regimen. ${ }^{18,87}$ Because COPD is a chronic disease, patients may receive long-term pharmacologic treatment. Therefore, nurse practitioners should be alert to the possibility of patients developing diseases for which COPD medications can be a risk factor, such as osteoporosis, diabetes, or cataracts. Nurse practitioners can play an important role in addressing and resolving these issues.

Communication between clinic staff and patients is critical to improving adherence and outcomes. ${ }^{88}$ The nurse practitioner is ideally situated to educate the patient on the nature of COPD, the lifestyle changes required, and realistic expectations of potential therapeutic benefits. Nurse practitioners can also provide instruction regarding proper use of devices and help patients to understand better the potential benefits and risks of treatments. The nurse practitioner may offer practical advice on the management of multiple therapies, such as creating a medication administration schedule tailored to suit individual lifestyles. In addition, the nurse practitioner can help to educate the patients about selfmonitoring of symptoms and can help to determine whether any dosage adjustments or other changes in treatment are required.

\section{Practical considerations for nurse practitioners}

Nurse practitioners play a key role in core teams managing the ongoing treatment of COPD. Handling patient concerns about safety and tolerability is an important aspect of the nurse practitioner's responsibilities, and may help to improve adherence to treatment. Therefore, it is important that the nurse practitioner establishes an ongoing dialog with patients, 
so as to understand their issues and concerns, and to provide practical education about their illness and its management and treatment.

Nurse practitioners should take a proactive approach to addressing safety and tolerability issues with patients when they are first prescribed a particular medication. Patients should leave the clinic with a good understanding of what side effects may occur, how serious the side effects may be, and what action they should take if a particular side effect occurs. The nurse practitioner should ascertain whether the patient already has any concerns that may prevent him or her from filling the prescription, and try to address them.

When a patient expresses a concern, nurse practitioners must recognize the need for an individual approach to that patient. They need to assess whether the concern stems from a side effect that the patient has actually experienced or a hypothetical concern based on something they have read or heard about. Some patients may be particularly bothered by minor side effects, and adherence is more likely to be a problem in these patients. Some side effects may present a more serious safety concern for certain patients (eg, those with existing cardiovascular disease). The nurse practitioner must assess the best approach, such as continuing with treatment and providing reassurance, continuing with treatment and taking steps to avoid or minimize the side effect, considering other medications or treatment options, or considering whether referral to a specialist is required. Patient concerns should be reassessed regularly. Importantly, the nurse practitioner can help patients to put the side effects they experience or fear into context, helping them to understand that appropriate treatment may be expected to reduce symptoms and exacerbations, and improve their quality of life, whereas they risk continued symptoms and possibly COPD exacerbations in the absence of adherence to treatment.

\section{Conclusion}

Despite the growing prevalence of COPD, a lack of knowledge and/or concerns about the side effects of medications can contribute to poor adherence with treatment in these patients. Nurse practitioners can play an important role in the management of the disease by providing patients with education and helping to monitor and individualize their treatments. In particular, nurse practitioners can help to address patients' concerns by providing them with information about the possible occurrence of side effects, advising them on appropriate action, and ensuring that they understand the balance between the potential benefits of treatment and the potential risks of side effects.

\section{Disclosure}

This article was developed on the basis of presentations and discussions at the Long-term Considerations in the Course and Treatment of COPD Taskforce meeting in Miami, FL, United States December 9-10, 2008, which was supported by Boehringer Ingelheim Pharmaceuticals Inc, and Pfizer Inc. Medical writing assistance, supported financially by Boehringer Ingelheim and Pfizer, was provided by Andrew Cooper of Envision Scientific Solutions, during the preparation of this review. Boehringer Ingelheim and Pfizer were given the opportunity to check the data used in the manuscript for factual accuracy only. PS has received editorial support funded by Boehringer Ingelheim and Pfizer. NH has received research grant support from GlaxoSmithKline, Boehringer Ingelheim, Novartis, Sepracor, AstraZeneca, and Dey Inc. He is on the speakers' bureaus of GlaxoSmithKline, Boehringer Ingelheim and AstraZeneca, and is a consultant to GlaxoSmithKline, Novartis, Boehringer Ingelheim, Sepracor, and Dey Inc.

\section{References}

1. Jemal A, Ward E, Hao Y, Thun M. Trends in the leading causes of death in the United States, 1970-2002. JAMA. 2005;294(10): $1255-1259$.

2. National Institutes of Health. Morbidity and mortality: 2009 chart book on cardiovascular, lung, and blood diseases. Available from: http://www. nhlbi.nih.gov/resources/docs/2009_ChartBook.pdf. Accessed July 5, 2012.

3. Mannino DM, Homa DM, Akinbami LJ, Ford ES, Redd SC. Chronic obstructive pulmonary disease surveillance - United States, 1971-2000. MMWR Surveill Summ. 2002;51(6):1-16.

4. Global Initiative for Chronic Obstructive Lung Disease. Global strategy for the diagnosis, management, and prevention of chronic obstructive pulmonary disease. Updated Dec 2011. Available from: http://www. goldcopd.org. Accessed July 5, 2012.

5. Belfer MH, Reardon JZ. Improving exercise tolerance and quality of life in patients with chronic obstructive pulmonary disease. JAm Osteopath Assoc. 2009;109(5):268-278.

6. Lopez AD, Shibuya K, Rao C, et al. Chronic obstructive pulmonary disease: current burden and future projections. Eur Respir J. 2006;27(2): 397-412.

7. Halbert RJ, Natoli JL, Gano A, Badamgarav E, Buist AS, Mannino DM Global burden of COPD: systematic review and meta-analysis. Eur Respir J. 2006;28(3):523-532.

8. Feenstra TL, van Genugten ML, Hoogenveen RT, Wouters EF, Rutten-van Mölken MP. The impact of aging and smoking on the future burden of chronic obstructive pulmonary disease: a model analysis in The Netherlands. Am J Respir Crit Care Med.2001;164(4): 590-596.

9. Mannino DM, Buist AS. Global burden of COPD: risk factors, prevalence, and future trends. Lancet. 2007;370(9589):765-773.

10. Celli BR, MacNee W, Agusti A, et al. Standards for the diagnosis and treatment of patients with COPD: a summary of the ATS/ERS position paper. Eur Respir J. 2004;23(6):932-946.

11. O'Donnell DE, Hernandez P, Kaplan A, et al. Canadian Thoracic Society recommendations for management of chronic obstructive pulmonary disease -2008 update - highlights for primary care. Can Respir J. 2008;15 Suppl A:1A-8A. 
12. Anthonisen NR, Connett JE, Enright PL, Manfreda J. Hospitalizations and mortality in the Lung Health Study. Am J Respir Crit Care Med. 2002;166(3):333-339.

13. Walters JA, Walters EH, Wood-Baker R. Oral corticosteroids for stable chronic obstructive pulmonary disease. Cochrane Database Syst Rev. 2005;3:CD005374.

14. Calverley PM, Anderson JA, Celli B, et al. Salmeterol and fluticasone propionate and survival in chronic obstructive pulmonary disease. N Engl J Med. 2007;356(8):775-789.

15. Tashkin DP, Celli B, Senn S, et al. A 4-year trial of tiotropium in chronic obstructive pulmonary disease. N Engl J Med. 2008;359(15): $1543-1554$

16. Celli B, Decramer M, Kesten S, Liu D, Mehra S, Tashkin DP. Mortality in the 4-year trial of tiotropium (UPLIFT) in patients with chronic obstructive pulmonary disease. Am J Respir Crit Care Med. 2009; 180(10):948-955.

17. Celli BR, Thomas NE, Anderson JA, et al. Effect of pharmacotherapy on rate of decline of lung function in chronic obstructive pulmonary disease: results from the TORCH study. Am J Respir Crit Care Med. 2008;178(4):332-338.

18. Restrepo RD, Alvarez MT, Wittnebel LD, et al. Medication adherence issues in patients treated for COPD. Int J Chron Obstruct Pulmon Dis. 2008;3(3):371-384.

19. Dahl R, Greefhorst LA, Nowak D, et al. Inhaled formoterol dry powder versus ipratropium bromide in chronic obstructive pulmonary disease. Am J Respir Crit Care Med. 2001;164(5):778-784.

20. Hanania NA, Darken P, Horstman D, et al. The efficacy and safety of fluticasone propionate $(250 \mathrm{microg}) / \mathrm{salmeterol}$ ( 50 microg) combined in the Diskus inhaler for the treatment of COPD. Chest. 2003;124(3): 834-843.

21. Boyd G, Morice AH, Pounsford JC, Siebert M, Peslis N, Crawford C. An evaluation of salmeterol in the treatment of chronic obstructive pulmonary disease (COPD). Eur Respir J. 1997;10(4):815-821.

22. Donohue JF, Parsey MV, Andrews C, et al. Evaluation of the efficacy and safety of levalbuterol in subjects with COPD. COPD. 2006;3(3): $125-132$.

23. Rennard SI, Anderson W, ZuWallack R, et al. Use of a long-acting inhaled beta2-adrenergic agonist, salmeterol xinafoate, in patients with chronic obstructive pulmonary disease. Am J Respir Crit Care Med. 2001;163(5):1087-1092.

24. Baumgartner RA, Hanania NA, Calhoun WJ, Sahn SA, Sciarappa K, Hanrahan JP. Nebulized arformoterol in patients with COPD: a 12-week, multicenter, randomized, double-blind, double-dummy, placebo- and active-controlled trial. Clin Ther. 2007;29(2):261-278.

25. Hanrahan JP, Hanania NA, Calhoun WJ, Sahn SA, Sciarappa K, Baumgartner RA. Effect of nebulized arformoterol on airway function in COPD: results from two randomized trials. COPD. 2008;5(1):25-34.

26. Casaburi R, Mahler DA, Jones PW, et al. A long-term evaluation of once-daily inhaled tiotropium in chronic obstructive pulmonary disease. Eur Respir J. 2002;19(2):217-224.

27. Kesten S, Jara M, Wentworth C, Lanes S. Pooled clinical trial analysis of tiotropium safety. Chest. 2006;130(6):1695-1703.

28. Taylor J, Kotch A, Rice K, et al. Ipratropium bromide hydrofluoroalkane inhalation aerosol is safe and effective in patients with COPD. Chest. 2001;120(4):1253-1261.

29. Rossi A, Kristufek P, Levine BE, et al. Comparison of the efficacy, tolerability, and safety of formoterol dry powder and oral, slow-release theophylline in the treatment of COPD. Chest. 2002;121(4):1058-1069.

30. Ohta K, Fukuchi Y, Grouse L, et al. A prospective clinical study of theophylline safety in 3810 elderly with asthma or COPD. Respir Med. 2004;98(10): 1016-1024.

31. Burge PS, Calverley PM, Jones PW, Spencer S, Anderson JA, Maslen TK. Randomised, double blind, placebo controlled study of fluticasone propionate in patients with moderate to severe chronic obstructive pulmonary disease: the ISOLDE trial. BMJ. 2000;320(7245): 1297-1303.
32. Pauwels RA, Löfdahl CG, Laitinen LA, et al. Long-term treatment with inhaled budesonide in persons with mild chronic obstructive pulmonary disease who continue smoking. European Respiratory Society Study on Chronic Obstructive Pulmonary Disease. NEngl J Med. 1999;340(25): 1948-1953.

33. Rennard SI, Tashkin DP, McElhattan J, et al. Efficacy and tolerability of budesonide/formoterol in one hydrofluoroalkane pressurized metereddose inhaler in patients with chronic obstructive pulmonary disease: results from a 1-year randomized controlled clinical trial. Drugs. 2009; 69(5):549-565.

34. Tashkin DP, Rennard SI, Martin P, et al. Efficacy and safety of budesonide and formoterol in one pressurized metered-dose inhaler in patients with moderate to very severe chronic obstructive pulmonary disease: results of a 6-month randomized clinical trial. Drugs. 2008;68(14): 1975-2000.

35. Aaron SD, Vandemheen KL, Hebert P, et al. Outpatient oral prednisone after emergency treatment of chronic obstructive pulmonary disease. N Engl J Med. 2003;348(26):2618-2625.

36. Alia I, de la Cal MA, Esteban A, et al. Efficacy of corticosteroid therapy in patients with an acute exacerbation of chronic obstructive pulmonary disease receiving ventilatory support. Arch Intern Med. 2011;171(21): 1939-1946.

37. Davies L, Angus RM, Calverley PM. Oral corticosteroids in patients admitted to hospital with exacerbations of chronic obstructive pulmonary disease: a prospective randomised controlled trial. Lancet. 1999; 354(9177):456-460.

38. Maltais F, Ostinelli J, Bourbeau J, et al. Comparison of nebulized budesonide and oral prednisolone with placebo in the treatment of acute exacerbations of chronic obstructive pulmonary disease: a randomized controlled trial. Am J Respir Crit Care Med. 2002;165(5):698-703.

39. Niewoehner DE, Erbland ML, Deupree RH, et al. Effect of systemic glucocorticoids on exacerbations of chronic obstructive pulmonary disease. Department of Veterans Affairs Cooperative Study Group. N Engl J Med. 1999;340(25):1941-1947.

40. Walters JA, Gibson PG, Wood-Baker R, Hannay M, Walters EH. Systemic corticosteroids for acute exacerbations of chronic obstructive pulmonary disease. Cochrane Database Syst Rev. 2009;1:CD001288.

41. Abramson MJ, Walters J, Walters EH. Adverse effects of beta-agonists: are they clinically relevant? Am J Respir Med. 2003;2(4):287-297.

42. Kelly HW. Risk versus benefit considerations for the $\beta_{2}$-agonists. Pharmacotherapy. 2006;26(9 Pt 2):164S-174S.

43. Salpeter SR, Ormiston TM, Salpeter EE. Cardiovascular effects of $\beta$-agonists in patients with asthma and COPD: a meta-analysis. Chest. 2004;125(6):2309-2321.

44. Suissa $\mathrm{S}$, Assimes T, Ernst P. Inhaled short acting $\beta$ agonist use in COPD and the risk of acute myocardial infarction. Thorax. 2003;58(1): 43-46.

45. Campbell SC, Criner GJ, Levine BE, et al. Cardiac safety of formoterol $12 \mu \mathrm{g}$ twice daily in patients with chronic obstructive pulmonary disease. Pulm Pharmacol Ther. 2007;20(5):571-579.

46. Rodrigo GJ, Nannini LJ, Rodríguez-Roisin R. Safety of long-acting $\beta$-agonists in stable COPD: a systematic review. Chest. 2008;133(5): 1079-1087.

47. Ferguson GT, Funck-Brentano C, Fischer T, Darken P, Reisner C. Cardiovascular safety of salmeterol in COPD. Chest. 2003;123(6): $1817-1824$.

48. Ogale SS, Lee TA, Au DH, Boudreau DM, Sullivan SD. Cardiovascular events associated with ipratropium bromide in COPD. Chest. 2010; 137(1):13-19.

49. Lee TA, Pickard AS, Au DH, Bartle B, Weiss KB. Risk for death associated with medications for recently diagnosed chronic obstructive pulmonary disease. Ann Intern Med. 2008;149(6):380-390.

50. Singh S, Loke YK, Furberg CD. Inhaled anticholinergics and risk of major adverse cardiovascular events in patients with chronic obstructive pulmonary disease: a systematic review and meta-analysis. JAMA. 2008;300(12):1439-1450 
51. Barr RG, Bourbeau J, Camargo CA, Ram FS. Tiotropium for stable chronic obstructive pulmonary disease: a meta-analysis. Thorax. 2006; 61(10):854-862.

52. Oba Y, Zaza T, Thameem DM. Safety, tolerability and risk benefit analysis of tiotropium in COPD. Int J Chron Obstruct Pulmon Dis. 2008;3(4):575-584.

53. Celli B, Decramer M, Leimer I, Vogel U, Kesten S, Tashkin DP. Cardiovascular safety of tiotropium in patients with COPD. Chest. 2010;137(1):20-30.

54. Atrovent ${ }^{\circledR}$ HFA [package insert]. Oct 2011. Available from: http:// bidocs.boehringer-ingelheim.com/BIWebAccess/ViewServlet. ser?docBase=renetnt $\&$ folderPath $=/$ Prescribing+Information/PIs $/$ Atrovent+HFA/10003001_US_1.pdf. Accessed July 5, 2012.

55. Gross NJ. Anticholinergic agents in asthma and COPD. Eur J Pharmacol. 2006;533(1-3):36-39.

56. Scullion JE. The development of anticholinergics in the management of COPD. Int J Chron Obstruct Pulmon Dis. 2007;2(1):33-40.

57. Michele TM, Pinheiro S, Iyasu S. The safety of tiotropium - the FDA's conclusions. N Engl J Med. 2010;363(12):1097-1099.

58. Brovana ${ }^{\circledR}$ [package insert]. Feb 2012. Available from: http://www. brovana.com/BrovanaApprovedLabelingText.pdf. Accessed July 5, 2012.

59. Foradil ${ }^{\circledR}$ Aerolizer $^{\circledR}$ [package insert]. Mar 2012. Available from: http:// www.spfiles.com/piforadil.pdf. Accessed July 5, 2012.

60. Serevent ${ }^{\circledR}$ Diskus $^{\circledR}$ [package insert]. Jan 2012. Available from: http:// us.gsk.com/products/assets/us_serevent_diskus.pdf. Accessed July 5, 2012.

61. Nelson HS, Weiss ST, Bleecker ER, Yancey SW, Dorinsky PM. The Salmeterol Multicenter Asthma Research Trial: a comparison of usual pharmacotherapy for asthma or usual pharmacotherapy plus salmeterol. Chest. 2006;129(1):15-26.

62. Chowdhury BA, Dal Pan G. The FDA and safe use of long-acting beta-agonists in the treatment of asthma. N Engl J Med. 2010;362(13): 1169-1171.

63. Spiriva ${ }^{\circledR}$ HandiHaler $^{\circledR}$ [package insert]. Mar 2012. Available from: http://bidocs.boehringer-ingelheim.com/BIWebAccess/ViewServlet. ser?docBase=renetnt $\&$ folderPath=/Prescribing+Information/PIs $/$ Spiriva/Spiriva.pdf. Accessed July 5, 2012.

64. MedlinePlus. Theophylline. Aug 2010. Available from: http://www.nlm.nih gov/medlineplus/druginfo/meds/a681006.html. Accessed July 5, 2012.

65. Flovent-HFA ${ }^{\circledR}$ [package insert]. Jan 2012. Available from: http://us.gsk.com/products/assets/us_flovent_hfa.pdf. Accessed July 5, 2012.

66. Pulmicort Flexhaler ${ }^{\circledR}$ [package insert]. Jul 2010. Available from: http://www1 .astrazeneca-us.com/pi/pulmicortfh.pdf. Accessed July 5, 2012.

67. Gartlehner G, Hansen RA, Carson SS, Lohr KN. Efficacy and safety of inhaled corticosteroids in patients with COPD: a systematic review and meta-analysis of health outcomes. Ann Fam Med. 2006;4(3) 253-262.

68. Crim C, Calverley PM, Anderson JA, et al. Pneumonia risk in COPD patients receiving inhaled corticosteroids alone or in combination: TORCH study results. Eur Respir J. 2009;34(3):641-647.

69. Kardos P, Wencker M, Glaab T, Vogelmeier C. Impact of salmeterol/ fluticasone propionate versus salmeterol on exacerbations in severe chronic obstructive pulmonary disease. Am J Respir Crit Care Med. 2007;175(2):144-149.

Journal of Multidisciplinary Healthcare

\section{Publish your work in this journal}

The Journal of Multidisciplinary Healthcare is an international, peerreviewed open-access journal that aims to represent and publish research in healthcare areas delivered by practitioners of different disciplines. This includes studies and reviews conducted by multidisciplinary teams as well as research which evaluates the results or conduct of such teams or
70. Wedzicha JA, Calverley PM, Seemungal TA, Hagan G, Ansari Z, Stockley RA. The prevention of chronic obstructive pulmonary disease exacerbations by salmeterol/fluticasone propionate or tiotropium bromide. Am J Respir Crit Care Med. 2008;177(1):19-26.

71. Drummond MB, Dasenbrook EC, Pitz MW, Murphy DJ, Fan E. Inhaled corticosteroids in patients with stable chronic obstructive pulmonary disease: a systematic review and meta-analysis. JAMA. 2008;300(20): 2407-2416.

72. Lung Health Research Group. Effect of inhaled triamcinolone on the decline in pulmonary function in chronic obstructive pulmonary disease. N Engl J Med. 2000;343(26):1902-1909.

73. Hubbard RB, Smith CJ, Smeeth L, Harrison TW, Tattersfield AE Inhaled corticosteroids and hip fracture: a population-based case-control study. Am J Respir Crit Care Med. 2002;166(12 Pt 1):1563-1566.

74. Lee TA, Weiss KB. Fracture risk associated with inhaled corticosteroid use in chronic obstructive pulmonary disease. Am J Respir Crit Care Med. 2004;169(7):855-859.

75. Johnell O, Pauwels R, Löfdahl CG, et al. Bone mineral density in patients with chronic obstructive pulmonary disease treated with budesonide Turbuhaler. Eur Respir J. 2002;19(6):1058-1063.

76. Ferguson GT, Calverley PM, Anderson JA, et al. Prevalence and progression of osteoporosis in patients with COPD: results from the TOwards a Revolution in COPD Health study. Chest. 2009;136(6):1456-1465.

77. Langhammer A, Forsmo S, Syversen U. Long-term therapy in COPD: any evidence of adverse effect on bone? Int J Chron Obstruct Pulmon Dis. 2009;4:365-380

78. Calverley PM, Rabe KF, Goehring UM, Kristiansen S, Fabbri LM, Martinez FJ. Roflumilast in symptomatic chronic obstructive pulmonary disease: two randomised clinical trials. Lancet. 2009; 374(9691):685-694

79. Fabbri LM, Calverley PM, Izquierdo-Alonso JL, et al. Roflumilast in moderate-to-severe chronic obstructive pulmonary disease treated with longacting bronchodilators: two randomised clinical trials. Lancet. 2009;374(9691):695-703.

80. Combivent ${ }^{\circledR}$ [package insert]. Sep 2011. Available from: http:// bidocs.boehringer-ingelheim.com/BIWebAccess/ViewServlet. ser?docBase=renetnt $\&$ folderPath=/Prescribing+Information $/$ PIs $/$ Combivent+IA/combivent.pdf. Accessed July 5, 2012.

81. Advair $^{\circledR}$ Diskus $^{\circledR}$ [package insert]. Sep 2011. Available from: http:// us.gsk.com/products/assets/us_advair.pdf. Accessed July 5, 2012

82. Symbicort ${ }^{\circledR}$ [package insert]. Jun 2010. Available from: http://www1. astrazeneca-us.com/pi/symbicort.pdf. Accessed July 5, 2012.

83. Moore PL. Practice management and chronic obstructive pulmonary disease in primary care. Am J Med. 2007;120(8 Suppl 1):S23-S27.

84. Barr RG, Celli BR, Mannino DM, et al. Comorbidities, patient knowledge, and disease management in a national sample of patients with COPD. Am J Med. 2009;122(4):348-355.

85. Nelson M, Hamilton HE. Improving in-office discussion of chronic obstructive pulmonary disease: results and recommendations from an in-office linguistic study in chronic obstructive pulmonary disease. $\mathrm{Am}$ J Med. 2007;120(8 Suppl 1):S28-S32.

86. Cramer JA, Bradley-Kennedy C, Scalera A. Treatment persistence and compliance with medications for chronic obstructive pulmonary disease. Can Respir J. 2007;14(1):25-29.

87. Laforest L, Denis F, Van Ganse E, et al. Correlates of adherence to respiratory drugs in COPD patients. Prim Care Respir J. 2010;19(2): 148-154.

88. Bourbeau J, Bartlett SJ. Patient adherence in COPD. Thorax. 2008;63(9): $831-838$.

\section{Dovepress}

healthcare processes in general. The journal covers a wide range of areas and welcomes submission from practitioners at all levels, from all over the world. The manuscript management system is completely online and includes a very quick and fair peer-review system. Visit http://www.dovepress.com/testimonials.php to read real quotes from published authors. 